\title{
Study on Identification and Evaluation of Environmental Factors in Bottled Water
}

\author{
Haihong Xin ${ }^{1, a}$, Fenfen Shi, ${ }^{1, b}$, Xiaoli Yan ${ }^{1, c}$ and Tingxin Wang ${ }^{1, d}$ \\ ${ }^{1}$ College of Quality and Technical Supervision, Hebei University, Baoding, China \\ ${ }^{1}$ Baoding engineering technology research center of dairy research development and quality control, \\ Baoding 071000, China

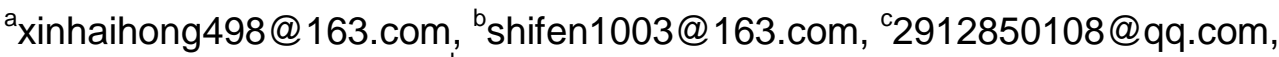 \\ dingxinwang@126.com
}

Keywords: Bottled water; Environmental factors; Process analysis; Multi - factor scoring method

\begin{abstract}
In order to effectively control the environmental factors and improve the environmental performance of enterprises, This article applies ISO14001 environmental management system thought, principle and method to analyze the environmental problems of bottled water production process, Taking a bottled water enterprise as an example, identify the environmental factors by applying the process analysis method, evaluate environmental factors using the multi-factor method, identify major environmental factors, so as to provide a reference for the small and medium-sized bottled water enterprises establishing targeted environmental management program.
\end{abstract}

\section{Introduction}

Bottled water, easy to drink and giving people the sense of security of water quality, is popular with the family, enterprises, social groups. With the price of drinking fountains reducing continuously, the bottled water sales market expand further, and the bottled water enterprises in the entire country's is driven to develop rapidly. Bottled water enterprises bring convenience to people, and the environmental impact caused by them cannot be ignored. According to the process of the aquatic products, bottled water can be divided into pure water, mineral water, distilled water, reverse osmosis water, space water, high oxygen water, active water and ecological water [1], and the bottled purified water is dominant. Regional bottled water companies usually don't have specialized personnel manage environment work, it also not establish effective control mechanism. For the status of environmental management is weak in the small and medium-sized bottled water business, this article take a bottled purified water enterprise belonged to a region of Hebei Province for example. Analysis and evaluate the key environmental factors of production process so as to provide a scientific method for enterprises identifying and evaluating environmental factors, and the basis for the development of targeted environmental control programs.

\section{The Theoretical Basis of Identification and Evaluation of Environmental Factors}

The identification and evaluation of environmental factors is the core content of the establishment of environmental management system[2]Life Cycle Assessment has been introduced into ISO14001: 2015 standard, which provides the basis for Planning, Implementation and Operation, Inspection, Improvement (PDCA), such as planning environmental policies and objectives, developing environmental management plans, implementing operational controls, contingency plans and monitoring and measuring them, all that are based on the identification and evaluation of environmental factors, and therefore environmental factor identification and evaluation is the core of the establishment of environmental management system[3].

Identification of environmental factors should follow principles :(1) The Comprehensive Principle of Environmental Factors Identification. Identify the environmental factors of organization's activities and services provision, these factors are able to control and influence (2) The Specificity Principle of Environmental Factors Identification. Environmental factors should be 
refined to be checked and verified traceability. (3) The Clarity Principle of Environmental Factors Identification. Identifying environmental factors should clear advantageous and adverse impact. (4) The Description Accuracy Principle of Environmental Factors Identification. Environmental factors may be described as a combination of pollutants name and an action.

There are many ways to identify environmental factors, such as process analysis, production cycle analysis of products, process flow material balance method, questionnaire survey, expert evaluation, site observation, To get objective and reasonable results, company should choose one or a combination of several methods base on the complexity of environment factors. Through site observation, process analysis and statistical methods, identify the factors and impact existing in process segment from input to output. Finally, summarize the same environmental impact or environmental factors having similar control method and make environmental factors summary table.

Environmental factor evaluation methods have judging right or wrong method, expert evaluation method, multi-factor score method, emission/frequency comparison method, equal-standard pollution load method, weighting method, etc. Among them, multi-factor evaluation is more commonly used method, the specific evaluation aspects are shown in Table 1.

Table 1 Scoring criteria for environmental factor evaluation

\begin{tabular}{|c|c|c|c|c|c|c|}
\hline $\begin{array}{l}\text { May } \\
\text { score }\end{array}$ & $\begin{array}{l}\text { The frequency o } \\
\text { environmental } \\
\text { impact (A) }\end{array}$ & of & $\begin{array}{l}\text { Scope of } \\
\text { environmental } \\
\text { impact (B) }\end{array}$ & $\begin{array}{l}\text { Recoverability or } \\
\text { sustainability of } \\
\text { environmental } \\
\text { impacts (C) }\end{array}$ & $\begin{array}{l}\text { the situation of } \\
\text { compliance with laws } \\
\text { and regulations }\end{array}$ & $\begin{array}{l}\text { stakeholders } \\
\text { concern } \\
\text { (D) }\end{array}$ \\
\hline 5 & $\begin{array}{l}\text { occur } \\
\text { continuously } \\
\text { once a day }\end{array}$ & to & Nationwide & $\begin{array}{l}\text { Irreversible } \quad \text { or } \\
\text { persistent }\end{array}$ & $\begin{array}{l}\text { Emissions exceed } \\
\text { standards. }\end{array}$ & Social concern \\
\hline 4 & $\begin{array}{l}\text { Once a day to } \\
\text { once a week }\end{array}$ & to & Reg & $\begin{array}{l}\text { More than half a } \\
\text { year can be restored }\end{array}$ & $\begin{array}{l}\text { Emissions slightly } \\
\text { higher than the } \\
\text { standard. }\end{array}$ & $\begin{array}{l}\text { Regional } \\
\text { concerns }\end{array}$ \\
\hline 3 & $\begin{array}{l}\text { Once a week to } \\
\text { once a month }\end{array}$ & to & Regional & $\begin{array}{l}\text { One week to half a } \\
\text { year can be restored }\end{array}$ & $\begin{array}{l}\text { Emissions meet the } \\
\text { standards. }\end{array}$ & $\begin{array}{l}\text { Corporate } \\
\text { sexual } \\
\text { concerns }\end{array}$ \\
\hline 2 & $\begin{array}{l}\text { Once a month to } \\
\text { once a year }\end{array}$ & & Corporation & $\begin{array}{l}\text { A day to one week } \\
\text { can be restored }\end{array}$ & $\begin{array}{l}\text { Emissions close to the } \\
\text { standard. }\end{array}$ & $\begin{array}{l}\text { Sectoral } \\
\text { concerns }\end{array}$ \\
\hline 1 & $\begin{array}{c}\text { More than once a } \\
\text { year }\end{array}$ & & $\begin{array}{l}\text { Small range } \\
\text { of minor } \\
\text { damage }\end{array}$ & $\begin{array}{c}\text { One day can be } \\
\text { restored }\end{array}$ & $\begin{array}{c}\text { Emissions below } \\
\text { standard }\end{array}$ & $\begin{array}{c}\text { Basically not } \\
\text { concerned }\end{array}$ \\
\hline
\end{tabular}

Any of the following situations is judged as major environmental factors. Such as monitoring indicators exceeded or close to excessive; Environmental factors concerned highly or monitored compulsorily by local government; Substances prohibited by government or law; Environmental factors concerned highly or complained reasonably by stakeholder; Environmental factors identified by company as governance point; Environmental factors not taken effective measures in the past. The score of environmental factor evaluation is

$$
X=A^{*} M
$$

$\mathrm{M}$ is the maximum of $\mathrm{B}, \mathrm{C}$ and $\mathrm{D}$, When $\mathrm{X}$ beyond to 20 , the environmental factor is judged as important environmental factor and regarded as the environmental management point.

The identification of bottled water enterprise's environmental factor about administrative offices, laboratories and treasury's is the same as other enterprises. The article mainly research the identification, evaluation and control of environmental factors, and apply process analysis method, supplemented by other methods to identify and evaluate bottled water business environment factors. 


\section{Identification of Environmental Factors in Bottled Water Enterprises}

Identification of environmental factors should start from process analysis, and do it one by one. Take a bottled purified water business' production line for example, the identifying process divide the production process into six stages. That's raw water collection, water pretreatment, water desalination, water sterilization, barrel disinfection and filling, water distribution.

Collection of Raw Materials. Raw water is from tap water factory. The water is delivered to workshop by pump and pipe. Water leakages happen in transportation if pipe inter isn't tight or with long time no maintenance. The results of environmental factors identification are shown in Table 2 .

Table 2 Identification of Environmental Factors in Raw Material Collection Process

\begin{tabular}{|c|c|c|c|c|}
\hline \multirow{2}{*}{$\begin{array}{l}\text { Raw material } \\
\text { collection } \\
\text { process }\end{array}$} & \multicolumn{2}{|c|}{ input } & \multicolumn{2}{|c|}{ Output } \\
\hline & $\begin{array}{l}\text { environmental } \\
\text { factor }\end{array}$ & $\begin{array}{l}\text { environmental } \\
\text { impact }\end{array}$ & environmental factor & environmental impact \\
\hline $\begin{array}{l}\text { The use of } \\
\text { pumps }\end{array}$ & $\begin{array}{l}\text { The use of } \\
\text { electricity }\end{array}$ & $\begin{array}{l}\text { Energy } \\
\text { consumption }\end{array}$ & Noise emissions & Noise Pollution \\
\hline $\begin{array}{l}\text { Maintenance of } \\
\text { the pump }\end{array}$ & $\begin{array}{l}\text { The use of } \\
\text { water }\end{array}$ & $\begin{array}{l}\text { Resource } \\
\text { consumption }\end{array}$ & $\begin{array}{l}\text { Wastewater generation } \\
\text { Waste generation }\end{array}$ & $\begin{array}{l}\text { Contaminated soil } \\
\text { Contaminated soil }\end{array}$ \\
\hline
\end{tabular}

Water Pretreatment. Most of particulate impurities and microorganisms are removed. Equipment such as sand filter, sodium ion exchange softener and activated carbon filter are needed, those should be cleaned before using, but also backwashed the other side of the membrane for a certain time. There may be water leakage in abnormal situation. Sodium ion exchange membrane, a polymer material, needs to be replaced regularly and buried. It needs time to be decomposed and can result soil pollution. The results of environmental recognition are shown in Table 3.

Table 3 Environmental factors identification table of pretreatment process

\begin{tabular}{|c|c|c|c|c|}
\hline \multirow{2}{*}{$\begin{array}{l}\text { Preprocessing } \\
\text { decomposition }\end{array}$} & \multicolumn{2}{|c|}{ input } & \multicolumn{2}{|c|}{ output } \\
\hline & $\begin{array}{l}\text { environmental } \\
\text { factor }\end{array}$ & $\begin{array}{l}\text { environmental } \\
\text { impact }\end{array}$ & environmental factor & environmental impact \\
\hline Filter operation & $\begin{array}{l}\text { electricity } \\
\text { using }\end{array}$ & $\begin{array}{l}\text { Energy } \\
\text { consumption }\end{array}$ & Noise emissions & sound pollution \\
\hline $\begin{array}{l}\text { Filter } \\
\text { maintenance }\end{array}$ & $\begin{array}{l}\text { membranes } \\
\text { using }\end{array}$ & $\begin{array}{l}\text { Resource } \\
\text { consumption }\end{array}$ & $\begin{array}{l}\text { Membrane } \\
\text { replacement } \\
\text { generation }\end{array}$ & Contaminated soil \\
\hline
\end{tabular}

Water Desalination. After the pretreatment, the organic precipitate, large particle impurity, part of the microorganism and the harmful gas are removed, but the soluble substance still exists. The purpose of desalination is to remove salt. Desalination equipment has permeator, pump, voltage regulator and the control filter. The environmental recognition results are shown in Table 4.

Table 4 Environmental factors identification table for desalting process

\begin{tabular}{|c|c|c|c|c|}
\hline \multirow{2}{*}{$\begin{array}{l}\text { Desalination } \\
\text { process } \\
\text { decomposition }\end{array}$} & \multicolumn{2}{|l|}{ input } & \multicolumn{2}{|l|}{ output } \\
\hline & $\begin{array}{l}\text { environmental } \\
\text { factor }\end{array}$ & $\begin{array}{l}\text { environmental } \\
\text { impact }\end{array}$ & environmental factor & environmental impact \\
\hline \multirow{2}{*}{$\begin{array}{l}\text { Equipment } \\
\text { operation }\end{array}$} & water using & $\begin{array}{l}\text { Resource } \\
\text { consumption }\end{array}$ & $\begin{array}{l}\text { Concentrated water discharge } \\
\text { Backwashing Wastewater }\end{array}$ & $\begin{array}{l}\text { Contaminated soil } \\
\text { Contaminated soil }\end{array}$ \\
\hline & $\begin{array}{l}\text { membranes } \\
\text { using }\end{array}$ & $\begin{array}{l}\text { Resource } \\
\text { consumption }\end{array}$ & $\begin{array}{l}\text { Membrane replacement waste } \\
\text { generation }\end{array}$ & Contaminated soil \\
\hline
\end{tabular}

Water Sterilization. The disinfection of barreled pure water adopts the ozone disinfection and use ozone generator and pump. There may be ozone leakage resulting air pollution in abnormal circumstances. The results of environmental recognition are shown in Table 5. 
Table 5 Identification of environmental factors in sterilization process

\begin{tabular}{|c|c|c|c|c|}
\hline \multirow{2}{*}{$\begin{array}{l}\text { Sterilization process } \\
\text { decomposition }\end{array}$} & \multicolumn{2}{|c|}{ input } & \multicolumn{2}{|c|}{ output } \\
\hline & $\begin{array}{l}\text { environmental } \\
\text { factor }\end{array}$ & $\begin{array}{l}\text { environmental } \\
\text { impact }\end{array}$ & environmental factor & environmental impact \\
\hline $\begin{array}{l}\text { The use of ozone } \\
\text { generators }\end{array}$ & $\begin{array}{l}\text { The use } \\
\text { electricity }\end{array}$ & $\begin{array}{l}\text { Energy } \\
\text { consumption }\end{array}$ & $\begin{array}{l}\text { Noise emissions } \\
\text { Ozone leakage }\end{array}$ & $\begin{array}{l}\text { Noise Pollution } \\
\text { Air Pollution }\end{array}$ \\
\hline The use of pumps & $\begin{array}{l}\text { The use } \\
\text { electricity }\end{array}$ & $\begin{array}{l}\text { Energy } \\
\text { consumption }\end{array}$ & Noise emissions & Noise Pollution \\
\hline
\end{tabular}

Barrel Disinfection and Filling. The process firstly cleans the outer manually then fill purified water in the disinfection filling machine. Disinfection filling machine may emerge chlorine dioxide leakage in abnormal situation. When the water pipes aren't strict, it may lead to water wasting. The barrel should be removed before cleaning, and discharge discarded lid. The final bottled water is stored in storehouse. The results of environmental factors identification are shown in Table 6.

Table 6 Identification of Environmental Factors in Cleaning, Disinfection and Filling Processes

\begin{tabular}{lllll}
\hline $\begin{array}{l}\text { Cleaning, } \\
\text { disinfection and } \\
\text { filling process }\end{array}$ & environmental factor & $\begin{array}{l}\text { environmental } \\
\text { impact }\end{array}$ & environmental factor & $\begin{array}{l}\text { environmental } \\
\text { impact }\end{array}$ \\
\cline { 2 - 5 } Barrel cleaning & $\begin{array}{l}\text { The use of cleaning } \\
\text { agents }\end{array}$ & $\begin{array}{l}\text { Resource } \\
\text { consumption }\end{array}$ & Waste liquid produced & $\begin{array}{l}\text { Contaminated } \\
\text { soil }\end{array}$ \\
$\begin{array}{l}\text { The use of } \\
\text { equipment }\end{array}$ & $\begin{array}{l}\text { The use of packaging } \\
\text { materials }\end{array}$ & $\begin{array}{l}\text { Resource } \\
\text { consumption }\end{array}$ & $\begin{array}{l}\text { The packaging } \\
\text { material results in } \\
\text { solid waste }\end{array}$ & $\begin{array}{l}\text { Waste of } \\
\text { resources }\end{array}$ \\
\hline
\end{tabular}

Water Distribution. If pure water only radiates to surroundings, the main vehicle is car. There be vehicle damage in emergency traffic accidents, water leakage. The results of environmental factors identification are shown in Table 7.

Table 7 Distribution process environmental factor identification table

\begin{tabular}{lllll}
\hline \multirow{2}{*}{$\begin{array}{l}\text { Distribution process } \\
\text { decomposition }\end{array}$} & $\begin{array}{l}\text { input } \\
\text { environmental } \\
\text { factor }\end{array}$ & $\begin{array}{l}\text { environmental } \\
\text { impact }\end{array}$ & environmental factor & Environmental impact \\
\hline \multirow{2}{*}{$\begin{array}{l}\text { The use of means of } \\
\text { transport }\end{array}$} & $\begin{array}{l}\text { The use of } \\
\text { gasoline } \\
\text { The use of } \\
\text { cars }\end{array}$ & $\begin{array}{l}\text { Energy } \\
\text { consumption } \\
\text { cesource } \\
\text { consumption }\end{array}$ & $\begin{array}{l}\text { Exhaust gas emissions } \\
\text { The damage of the cars }\end{array}$ & Air Pollution \\
\hline
\end{tabular}

\section{The Evaluation of Bottled Water Companies Environmental Factors}

Summarize the environmental factors involved in processes. In the preliminary investigation, site survey method was used to inspect the sewage disposal point, factory's environment, the operation status of equipment, the tightness of pipeline and the solid waste disposal; Through the interrogation method and talking to the workshop staff, ask the operation method and the flow and observe the normative of operation, ask local residents about the degree of concern and complaints of enterprise, whether there is odor, solid waste, noise pollution affecting their lives; Ask the person in charge of production department the enterprise's power and water consumption, the proportion of purified water and raw water consumption, Score and evaluate environmental factors according to the survey and with reference to Table 1, the results of the evaluation are shown in Table 8. 
Table 8 Evaluation of Environmental Factors

\begin{tabular}{|c|c|c|c|c|c|c|c|}
\hline Activities / services & Environmental factor & $\mathrm{A}$ & $\mathrm{B}$ & $\mathrm{C} \mathrm{I}$ & $\mathrm{DX}$ & Tense/ state & results \\
\hline $\begin{array}{l}1 \text { raw water collection; } \\
\text { water pretreatment; } \\
\text { water desalination; }\end{array}$ & $\begin{array}{l}\text { electricity, water using in the } \\
\text { operation of Equipment (pumps, } \\
\text { filling machines, filters) }\end{array}$ & 5 & 1 & 11 & 15 & now/normal & general \\
\hline $\begin{array}{l}\text { water sterilization; } \\
\text { barrel disinfection and } \\
\text { filling }\end{array}$ & $\begin{array}{l}\text { Noise emissions from equipment } \\
\text { operation(Pumps, filling machines, } \\
\text { filters) }\end{array}$ & 5 & 2 & 12 & 210 & now/normal & general \\
\hline $\begin{array}{l}2 \text { raw water collection; } \\
\text { water pretreatment; }\end{array}$ & $\begin{array}{l}\text { The use of water in equipment } \\
\text { maintenance }\end{array}$ & 3 & 1 & 22 & 26 & ormal & general \\
\hline $\begin{array}{l}\text { water desalination; } \\
\text { water sterilization; } \\
\text { water distribution. }\end{array}$ & $\begin{array}{l}\text { The production of wastewater in } \\
\text { equipment maintenance }\end{array}$ & 3 & 3 & 22 & 26 & future/normal & general \\
\hline $\begin{array}{l}3 \text { raw water collection; } \\
\text { water pretreatment; }\end{array}$ & $\begin{array}{l}\text { Water leakage during water } \\
\text { transport }\end{array}$ & 3 & 1 & 23 & 39 & future/abnormal & general \\
\hline water desalination & Pipeline replacement waste & 3 & 1 & 22 & 26 & future/normal & general \\
\hline 4 water pretreatment; & $\begin{array}{l}\text { Wastewater generation } \\
\text { Membrane replacement waste }\end{array}$ & $\begin{array}{l}5 \\
1\end{array}$ & & & $\begin{array}{ll}3 & 15 \\
4 & 4\end{array}$ & $\begin{array}{l}\text { now/ normal } \\
\text { future/ normal }\end{array}$ & $\begin{array}{l}\text { general } \\
\text { general }\end{array}$ \\
\hline 5 water desalination & $\begin{array}{l}\text { Wastewater generation } \\
\text { waste generation } \\
\text { Ozone leakage } \\
\text { Water leakage }\end{array}$ & $\begin{array}{l}5 \\
1 \\
2 \\
3\end{array}$ & $\begin{array}{l}3 \\
4 \\
2 \\
1\end{array}$ & $\begin{array}{ll}4 & 2 \\
4 & 4 \\
1 & 3 \\
2 & 2\end{array}$ & $\begin{array}{ll}2 & 20 \\
4 & 4 \\
3 & 6 \\
2 & 6\end{array}$ & $\begin{array}{l}\text { now/ normal } \\
\text { future/normal } \\
\text { future/abnormal } \\
\text { future/abnormal }\end{array}$ & $\begin{array}{l}\text { important } \\
\text { general } \\
\text { general } \\
\text { general }\end{array}$ \\
\hline 6 barrel disinfection & Wastewater, waste discharge & 5 & 1 & 23 & $3 \quad 15$ & now/ normal & general \\
\hline and filling, & $\begin{array}{l}\text { Solid waste generation } \\
\text { Chlorine dioxide leakage }\end{array}$ & $\begin{array}{l}5 \\
2\end{array}$ & $\begin{array}{l}3 \\
1\end{array}$ & $\begin{array}{ll}5 & 3 \\
2 & 2\end{array}$ & $\begin{array}{ll}3 & 25 \\
2 & 4\end{array}$ & $\begin{array}{l}\text { now / normal } \\
\text { future/abnormal }\end{array}$ & $\begin{array}{l}\text { important } \\
\text { general }\end{array}$ \\
\hline 7 water distribution. & $\begin{array}{l}\text { Exhaust emissions } \\
\text { Pure water leakage } \\
\text { Accidental damage to the car } \\
\text { Solid waste generation }\end{array}$ & $\begin{array}{l}5 \\
2 \\
2 \\
3\end{array}$ & $\begin{array}{ll}4 & 5 \\
1 & 1 \\
3 & 2 \\
3 & 5\end{array}$ & $\begin{array}{ll}4 & 4 \\
1 & 3 \\
2 & 3 \\
5 & 3 \\
\end{array}$ & $\begin{array}{ll}4 & 20 \\
3 & 3 \\
3 & 6 \\
3 & 15 \\
\end{array}$ & $\begin{array}{l}\text { now/ normal } \\
\text { future / urgent } \\
\text { future / urgent } \\
\text { future/ normal }\end{array}$ & $\begin{array}{l}\text { important } \\
\text { general } \\
\text { general } \\
\text { general }\end{array}$ \\
\hline
\end{tabular}

Note: Environmental factors with an $\mathrm{X}$ value greater than 20 are important environmental factors.

\section{Conclusions}

We can formulate targeted management programs reducing environmental impact and improve environmental performance through the identification and evaluation of environmental factors. The core and foundation of system is the evaluation and identification of important environmental and organization environmental factors. And it forward to the control requirements and the goals to be achieved about the important environmental factors. Environmental management system elements carry out activities based on this. In this paper, we focus on the identification of environmental factors and evaluate the key environmental factors in order to provide a scientific method developing targeted environmental management programs. Finally improve environmental performance and continuously improve the level of enterprise environmental management.

\section{Acknowledgments}

This work was supported by Hebei province sofe science project (14456213D) and Hebei province social science fund project (HB15GL131)

\section{References}

[1] C.M Wang. the Tnvestigation and Analysis of Yuhua District Urban Drinking Water Changsha City [J].Water Resources \& Hydropower Engineering,Vol.3(2012),pp86-87

[2] F.M Wu. Identification and Evaluation of Environmental Factors in Hydropower Project

[3] Construction [J]. China Certification \& Accreditation,Vol.3(2014),pp29-30 
[4] Z.G Gu. Study on the Implementation of Identifying Environmental Factors from the Perspective of Life Cycle [J]. China Certification \& Accreditation,Vol.3(2016),pp35-37

[5] B Mu. Wang, C Ting, and X.G Ding. Discussion on identification and evaluation method of important environmental factors in petrochemical enterprises [J].Safety Health \& Environment,Vol.9(2011),pp.15-17

[6] B.C Lin. Study on the Identification, Evaluation and Control of Environmental Factors in ISO14001 Environmental Management System [J]. Guangdong Chemical Industry,Vol.5(2014),pp.214-216

[7] Taylor. HACCP for the hospitality industry: a psychological model for success. International Journal of Contemporary Hospitality Management, 2008, 20(5),508 523.

[8] Wassan Rano Khan, Majid Mohd Amin Abd, and Mokhtar Ainul Akmar. Risk matrix model for Rotating equipment, MATEC Web of Conferences, Vol.13, 2014.

[9] Zhou Ping Ping, Zhao Ping Liu, Lei Zhang, Ai Dong Liu, Yan Song, Ling Yong, and Ning Li.

[10] Methodology and application for health risk classification of chemicals in foods based on risk Matrix, Biomed Environ Sci, Vol.27, 2014.

[11]Liu Qing Jun, Ting Chen, Jing Hua Zhang, and Tan Wang. Food safety risk is monitoring model Based on risk matrix, Food Science, vol.5, 2010, pp.86-90.

[12]Huang Xiao Juan, and Bei Lin Liu. The food safety risk early warning index system design and research, Journal of Harbin University of Commerce(Natural Sciences Edition),vol.5, pp.621-629, 2008. 